October 2014

\title{
Why Christians Are Afraid of Removing Artificial Nutrition and Hydration
}

Lynley G. Turkelson

Cedarville University, lynleyturkelson@cedarville.edu

DigitalCommons@Cedarville provides a publication platform for fully open access journals, which means that all articles are available on the Internet to all users immediately upon publication. However, the opinions and sentiments expressed by the authors of articles published in our journals do not necessarily indicate the endorsement or reflect the views of DigitalCommons@Cedarville, the Centennial Library, or Cedarville University and its employees. The authors are solely responsible for the content of their work. Please address questions to dc@cedarville.edu.

\section{Recommended Citation}

Turkelson, Lynley G. (2014) "Why Christians Are Afraid of Removing Artificial Nutrition and Hydration," CedarEthics: A Journal of Critical Thinking in Bioethics: Vol. 13 : No. 2 , Article 2.

DOI: $10.15385 /$ jce.2014.13.2.2

Available at: http://digitalcommons.cedarville.edu/cedarethics/vol13/iss2/2 


\title{
Why Christians Are Afraid of Removing Artificial Nutrition and Hydration
}

Browse the contents of this issue of CedarEthics: A Journal of Critical Thinking in Bioethics.

\begin{abstract}
On 31 March 2005, Terri Schiavo passed away, amidst the grief, consternation, and outrage of many Americans. In our desire to live forever and "be like God" (Genesis 3:5), human beings have created deathdefying technologies. However, these technologies have led to many ethical dilemmas, in part because bioethics has been influenced insidiously by a cultural transhumanism that denies our fundamental human nature and mortality. Many Christians have embraced a transhumanist view of technology, leading to an unhealthy vitalism at the end of life. In this paper, I will demonstrate this flawed view, using the persistent vegetative states (PVS) as an example.
\end{abstract}

\section{Keywords}

Christians, transhumanism

\section{Creative Commons License}

\section{(ब) (1)}

This work is licensed under a Creative Commons Attribution-Noncommercial-No Derivative Works 4.0 License.

Follow this and additional works at: http://digitalcommons.cedarville.edu/cedarethics

Part of the Bioethics and Medical Ethics Commons 


\title{
Why Christians are Afraid of Removing Artificial Nutrition and Hydration
}

\author{
Lynley G. Turkelson \\ Cedarville University
}

\begin{abstract}
$\mathrm{O}$ n 31 March 2005, Terri Schiavo passed away, amidst the grief, consternation, and outrage of many Americans. In our desire to live forever and "be like God" (Genesis 3:5), human beings have created death-defying technologies. However, these technologies have led to many ethical dilemmas, in part because bioethics has been influenced insidiously by a cultural transhumanism that denies our fundamental human nature and mortality. Many Christians have embraced a transhumanist view of technology, leading to an unhealthy vitalism at the end of life. In this paper, I will demonstrate this flawed view, using the persistent vegetative states (PVS) as an example.
\end{abstract}

\section{The Influence of Transhumanism}

Lisa Cahill (2005) suggests that modern medical science and technology form the primary "hermeneutical framework" wherein Christians think about death (p. 70). This has led, I believe, to a transhumanist framework that has permeated the way Christians contemplate life, death, and the purpose of both.

Mitchell defines transhumanism as a gnostic perspective of the body (everything physical is evil) combined with a utopian vision for society (pursuit of perfection). We overcome our finitude and achieve utopia through the use of technology (George, 2013). Consequently, transhumanists loathe the limitations of the human physical body and the prospect of suffering and death (Mitchell \& Kilner, 2003). This loathing, combined with a strong emphasis on individual rights, leads to a pursuit of physician assisted suicide (PAS); individuals would rather choose death than face dying in the context of a failing human body. In his work Neither Beast Nor God, Meileander (2009) aptly suggests that our own human nature is at the center of emerging transhumanism: "Our greatest temptation may be to use our powers of mind and soul to control and master our bodies - to be more than human" (p. 5). Indeed, efforts to become more than human are at the very heart of transhumanist thought.

Christians may believe that they are immune to such influences. However, staunchly pro-life Christians as well as modern advocates for life-ending measures fall into the same trap: they both view dying primarily as a medical event, best dealt with through technology. For Christians, this takes the form of vitalism. Christian vitalism sees life as an end in itself to be pursued at any cost, resulting in misguided efforts to control death (Loewy, 1991). The transhumanist influence on Christian vitalism is especially evident in Christian perspectives on the use of artificial nutrition and hydration (ANH) and its role in the treatment of PVS. 


\section{When to Use Treatments}

To begin, we must first examine the principle of proportionate v. disproportionate treatment. In the past, the terms "ordinary" and "extraordinary" were used to determine the usefulness and necessity of a treatment. However, the language of proportionality and disproportionality better captures the nature of the discussion: it is not whether treatment is ordinary, but rather if treatment is best suited to the circumstances and needs of the patient. The word extraordinary implies the patient may be receiving more treatment than deserved or that extraneous measures are being taken, instead of focusing on whether the treatment is proportionate to specific needs of specific patients. Proportionality language helps us to ask more valuable questions: is the treatment proportionate to the illness, or is treatment falling short of treatment goals for this patient (disproportionate)? A focus on patient needs and treatment goals removes any sort of hedonic calculus analyzing whether or not the patient in question deserves treatment (Orr \& Meileander, 2004).

The proportionality or disproportionality of a treatment is not predetermined, nor is it stable over time. When considering proportionality, the physician accounts for both burdens and benefits of the treatment based on the prognosis (Orr \& Meileander, 2004). Cahill (2005) also suggests that ongoing determinations of proportionality take into consideration availability and cost of treatment, the "physical and moral resources" of the patient, and the patient's personal wishes (p. 107). From a clinical prospective, Kuhse (1997), a nurse and bioethicist, approaches from the standpoint of what she terms "dispositional care:" discerning a person's specific needs and interests and creating a plan of care based on that discernment (p. 170).

\section{Technology and Human Finitude}

For a patient who is otherwise healthy, the presumed treatment goal is to return the individual to his or her prior healthy state (Hickman, Hammes, Moss, \& Tolle, 2012). However, for those who can no longer recover, treatment goals shift to comfort care. Why is this? Because the treatment no longer fulfills its purpose to help the patient get better. Normally, when a patient receives $\mathrm{ANH}$, the feeding tube is used to compensate for the patient's lack of ability to feed himself because of illness or injury.

Psychologically speaking, removing a failing treatment may be difficult for family and friends, but they must realize that the treatment is not actually improving the condition of their loved one (Orr \& Meileander, 2004). The discontinuing of a disproportionate treatment is ethically sound because the treatment has failed in its goal. The passing of the individual may be an unfortunate result of removing the treatment, but this is not choosing death. Meileander (2004) makes this point well: "in refusing [treatment like $\mathrm{ANH}$ ] one is not choosing death but life without a now useless form of treatment" (p. 10).

For those who may worry that removal of ANH is somehow "starving" the patient it should be noted that the patient does not die from starvation, but lack of hydration. Numerous studies have shown that patients do not suffer from dehydration, as long as the mouth is kept moist. After all, dehydration is often the final physiological stage in the progression towards death, regardless of circumstances (Orr \& Meileander, 2004). Additionally, in many end of life circumstances, ANH 
only creates further complications such as nausea, swelling, and vomiting, among other difficulties (Baylor Health Care System, 2010).

This information typically does not convince modern evangelical Christians in regard to the removal of ANH. Why? I believe it is due an inappropriate, transhumanist reliance on technology and a denial of the limits of science. Pope John Paul II is a recent example of how transhumanist beliefs have permeated Christian thought. In a published address, he taught that ANH is basic care, and a natural (not medical) means to preserve life (Ethical and Religious Directives, 2009). However, Cahill (2005) counters that this view "normalizes" medical technology and "medicalizes" basic human needs (p. 109).

When nutrition is no longer a reasonable goal of treatment, we should accept this reality. Before the advent of feeding tubes, the goal was simply to make patients in the last stages of life as comfortable as possible. Medical personnel and loved ones were not concerned about feeding the dying patient per se, because they acknowledged that the patient was dying. So our use of a feeding tube in those near death is also inappropriate today.

Of course, I am not arguing that ANH is inappropriate for dying patients, simply because it was not used in the past. Instead this reminds us that not all treatment measures are appropriate simply because they are available. Our indiscriminate use of technology refuses to see the limits of science to prevent death.

\section{The Results of Transhumanism}

What is wrong with embracing medical technology in order to preserve life? Aside from the fact that technology is often used inappropriately, Christians must examine the motives behind such life-prolonging pursuits. Transhumanism, by definition, loathes the idea of human finitude and attempts to defy it through technology. "It is all too tempting," says Dresser (2005), " to look away from people who are obviously ill, in part because they are reminders of human frailty and mortality" (p. 510). Death opposes human pride by solidifying the knowledge that humans "are but dust" (Psalm 103:14, NASB). I believe this denial of mortality is fundamentally rooted in a fear of death.

When death is viewed through a medical-technological hermeneutic, dying becomes an unfortunate medical event that should be avoided at all costs (Cahill, 2005). Because of the great progress of medical technology, our lifespan has been extended and death assigned to old age. Since death appears so distant, we view dying as a monstrous intrusion into human life, rather than a normal part of it. Death, however, is not to be feared by the Christian; death is merely the final act of a believer before receiving the hope of eternal life (MacArthur, 2009). This idea is best seen in 1 Corinthians 15:20-22 (ESV): "But in fact Christ has been raised from the dead...For as by a man came death, by a man has come also the resurrection of the dead. For as in Adam all die, so also in Christ shall all be made alive... The last enemy to be destroyed is death." Christ has triumphed over death, so each believer has also. 
The influence of transhumanist Gnosticism and utopianism is evident in Christian attitudes towards death. When life is pursued at any cost and death is denied, it is often a symptom of striving after a utopian ideal. This attitude refuses to accept the limits of science and medicine in preserving life, and it denies the fundamental nature of humans to die (Genesis 3 ). We are not the evolving post-humans that transhumanists would like us to believe. There is "a time to be born and a time to die" (NET Bible), writes the author of Ecclesiastes in chapter 3. "God has made everything fit beautifully in its appropriate time, but $\mathrm{He}$ has also placed ignorance in the human heart so that people cannot discover what God has ordained, from the beginning to the end of their lives" (v. 11).

Gnosticism - a denial of the importance of the body - is evident in the transhumanist elevation of mind over body. However, a Christian hermeneutic recognizes that the body is inexorably linked to spirit of the person, based on the bodily resurrection of Christ and eventually of all believers. Human beings are not merely a mind encased in a body. Respecting the body's natural progression towards death is not only theologically sound, but it also helps us define "burdensome" treatment. The passing of loved-ones is viewed not as a loss in the fight for life, but acceptance of the limits of fallen human life.

\section{The Persistent Vegetative State}

The clouding influence of transhumanist Christian vitalism is most evident in debates about the role of ANH in PVS. The chief ethical concern with removing ANH is that individuals in PVS are not actually dying. First, the diagnosis of PVS is not always straightforward; it can take from one month to a few years to establish the diagnosis after treatment proves ineffective. So ANH is completely appropriate to sustain patients while physicians make this determination. However, refractory patients who are clearly in PVS have no hope of a meaningful interaction with others; it is our transhumanist mindset that prevents us from acknowledging this. In the case of PVS, Christians must ask themselves two fundamental questions: what is the purpose of our life, and are we artificially postponing death in a denial of human mortality?

Regarding the first question, Cahill (2005) articulates a clear, theology-centered answer: the purpose of life is shared community and pursuit of spiritual relationship. While Christians rightly reject the reasoning that ANH should be discontinued because PVS individuals are "not useful to society," the inability of the individual to participate in human experience is a serious handicap. In Jeremiah 29:11, God gives reassurance to Israel, reminding His chosen people that he has a plan for them. Christians should note that God's plans, though not known specifically, include hope for the future. While we cannot know the future of individuals who are severely disabled, we know such a future does exist. The future of individuals in PVS is fairly clear. Maximum recovery to a minimally conscious state is rare, and it is debatable to what extent minimally conscious individuals are actually conscious.

The reality of sustaining PVS patients for years in hopes of recovery raises another consideration: has Christian vitalism emphasized life to the point of excluding all other Christian virtues such as stewardship and social justice? O'Brien, Slosar, and Tersigni (2004) speak well to the issue of social justice and medical resources: 
It could be argued that considerations of distributive justice, responsible stewardship, and the common good would require dedicating our health-care resources first to rectifying some of the fundamental inequities in the current structure . . . in this country, before dedicating any resources to "awakening centers" that may or may not have any impact on outcomes (p. 510).

Relinquishing the life of a loved one in PVS does not mean one diminishes the value of human life, but rather that one selflessly recognizes the potential to help others by properly stewarding medical resources. Additionally, if ANH is a moral imperative, the lack of ANH across cultures should represent an overwhelmingly under-addressed human-rights crisis. As of yet, such a crisis remains unrecognized.

\section{The Mind the Body and PVS}

Humans, by definition, are an integration of the body and mind — the mind and brain are tied together in such beautifully complex ways that no human can truly comprehend this. We do not have access to the spirit or soul apart from its "incarnation in the body" (Meileander, 2013, p. 6). When the brain has decayed to the point of no longer functioning except through basic, programmed reflexes (PVS), it is not unreasonable to assume that the mind, soul, or spirit of that individual has also departed.

Christian adaptations of gnostic notions (which value the mind's significance over the body) push care givers to continue ANH in bodies in PVS - Christians fail to see the complete compromise of the brain and body as sufficient evidence that the spirit may have departed. Instead Christians consider the mind and body separate entities, and place high importance on the vague possibility that a mind may still be present within the body of an individual in PVS.

\section{Christ, Not Vitalism, is Our Life}

Doctors in the West remain baffled at their inability to successfully facilitate the transition to death, despite the fact that countries like the United States spend far more financial resources on medical technology than non-western countries (Cahill, 2005). Could it be that medicine and technology cannot adequately address the significance of the transition to death? Ultimately, Christians must realize that vitalism does not honor human dignity, but lessens it. In the prudent words of Gilbert Meileander (2009), "we are increasingly tempted to see our problems . . . as bodily problems to be medicated away as if we were less than human [emphasis added]" (p. 5). The difficulties of life are no longer opportunities to develop character and faith (James 1), but medical disorders necessitating treatment.

In discussing human dignity among the severely ill, Dresser (2009) points out that the word dignity, used in an end-of-life context, is often a veiled argument for patient autonomy in decision-making. In the same way, vitalism, although well intentioned, does not always protect human dignity and life. In the case of PVS, I believe vitalism merely reflects the transhumanist lens that Christians have unknowingly assumed. Death is best handled, not by transhumanism that ultimately dismisses the person, but in the context of supportive churches, families, and friendships. As the body of Christ, we must rise up and bravely begin to actively care for, mourn 
with, and comfort dying individuals and their families. The support of the church is ultimately an acknowledgement of human limits, allowing death to become a spiritually meaningful experience, which ends not in a hospital room, but in eternal life.

\section{References}

Cahill, L. S. (2005). Theological bioethics: Participation, justice, and change. Washington, DC: Georgetown University Press.

Baylor Health Care System (2014). Common questions and answers about artificial nutrition and hydration. Office of Clinical Ethics and Palliative Care. Available at https://www.baylorhealth.com

Dresser, R. (2009). Human dignity and the seriously ill patient. In E. D. Pellegrino, A. Schulman, \& T. W. Merrill (Eds.), Human dignity and bioethics (pp. 505-512). Notre Dame, Ind.: University of Notre Dame Press.

Ethical and Religious Directives for Catholic Health Care Services (5th ed., 2009) United States Conference of Catholic Bishops. Washington, DC.

C. Ben Mitchell. Beeson podcast (2013, July 30). Beeson Divinity School. Available at: http://www.beesondivinity.com/

Hickman, S. E., Hammes, B. J., Moss, A. H., \& Tolle, S. W. (2012). Hope for the future: Achieving the original intent of advance directives. In C. Levine (Ed.), Taking sides: Clashing views on bioethical issues (14th ed.).

Kuhse, H. (1997). Caring: Nurses, women, and ethics. Oxford, OX, UK: Blackwell. Loewy, E. H. (1991). Suffering and the beneficent community: Beyond libertarianism. Albany: State University of New York Press.

MacArthur, J. (2009). Right thinking in a world gone wrong. Eugene, Or.: Harvest House.

Meilaender, G. (2009). Neither beast nor God: The dignity of the human person. New York: Encounter Books.

Meilaender, G. (2013). Bioethics: A primer for Christians (3rd ed.). Grand Rapids, MI: Wm. B. Eerdmans Publishing Co.

Mitchell, C. B., \& Kilner, J. F. (2003, August 29). Remaking humans: The new utopians versus a truly human future. Center for Bioethics and Human Dignity. Available at: http://cbhd.org/content/remaking-humans-new-utopians-versus-truly-human-future 
O'Brien, D., Slosar, J. P., \& Tersigni, A. R. (2004). Utilitarian pessimism, human dignity, and the vegetative state: a practical analysis of the papal allocution. National Catholic Bioethics Quarterly, 4(3), 497-512.

Orr, R. D., \& Meileander, G. (2004). Ethics \& life's ending. First Things, (145), 31-35.

Sullivan, D. (2013, November 5). Personal Communication. 